\title{
PCR detection of HIV proviral DNA (gag) in the brains of patients with AIDS: comparison between results using fresh frozen and paraffin wax embedded specimens
}

S F An, A Ciardi, F Scaravilli

\begin{abstract}
Aims-To adapt the polymerase chain reaction (PCR) technique of HIV detection to paraffin wax embedded brain tissue and to compare the results with those obtained using frozen tissue.

Methods-HIV antigen and HIV proviral DNA were detected in specimens of frontal lobe using immunohistochemistry and PCR, respectively. DNA was extracted from fresh tissue using standard methods whereas the technique for extracting DNA from paraffin wax embedded tissue was partly modified. Results-Twenty cases were examined. HIV DNA was detected in 16 cases in frozen specimens. Of these, 15 were also positive when paraffin wax embedded material was analysed.

Conclusions-This study shows that HIV proviral DNA can be detected in formalin fixed, paraffin wax embedded brain tissue by PCR. The results obtained from paraffin wax embedded specimens showed a similar degree of reliability to those from fresh frozen brain. Factors such as fixative, fixation time, and delay in performing post mortem examinations did not seem to influence PCR amplification as positive results were obtained with specimens left in fixative for up to eight months, as well as in cases where post mortem examinations had been delayed for up to four days.
\end{abstract}

(f Clin Pathol 1994;47:990-994)

The polymerase chain reaction (PCR), which permits specific and rapid amplification of nucleic acid sequences from a variety of tissues, has also been used to detect HIV DNA in brain tissue of patients with AIDS and of HIV positive subjects. ${ }^{1-6}$ In previous studies carried out in this department Sinclair and Scaravilli ${ }^{2}$ and Sinclair $e t a l^{3}$ have successfully used fresh frozen samples from brain tissue obtained at post mortem examination. However, fresh HIV positive specimens represent a safety hazard which considerably restricts their use. By contrast, formalin fixed, paraffin wax embedded tissue has several advantages: this fixative renders the tissue non-infectious and prevents further deterioration of proteins and nucleic acids.?

Moreover, as embedding formalin fixed material in paraffin wax is the most widely used method in histopathology, application of
PCR to this tissue would enable large retrospective studies to be undertaken and permit comparison of material without risk of contamination. To be acceptable, however, this technique must not only yield reproducible results but its rate of success must be comparable with that using fresh tissue.

The purpose of this study was, therefore, to adapt the PCR technique used to detect HIV proviral DNA in frozen tissue to paraffin wax embedded specimens and to compare the results obtained using each technique.

\section{Methods}

Twenty brains of patients with AIDS, from which both fresh frozen and paraffin wax embedded specimens were available, were chosen from the files of the Department of Neuropathology, Institute of Neurology, London. The frontal poles of brain obtained at post mortem examination were removed and frozen whilst the rest of the brain was fixed in $10 \%$ buffered formalin for a variable length of time (table). Fifteen blocks were taken from each case and routinely processed for histology. For the purpose of this study, paraffin wax embedded tissue from sites adjacent to the frozen sample was used.

\section{IMMUNOHISTOCHEMISTRY}

The primary antibody HIV p24 (Du Pont Diagnostics, Stevenage, UK), which detects the HIV core protein p24, was used to screen paraffin wax embedded sections of anterior frontal lobes from all cases in this study. Briefly, paraffin wax embedded sections were dewaxed and endogenous peroxidase was blocked with $0.03 \%$ hydrogen peroxide in methanol. Incubation for one hour with primary antibody (HIV p24) was followed by incubation with biotinylated rabbit anti-mouse (30-60 minutes) and peroxidase conjugated avidin (30 minutes). 3,3'Diaminobenzidine was used as a substrate to reveal the peroxidase.

DNA was extracted as previously described by Pang et $a l^{8}$ and Sinclair and Scaravilli. ${ }^{2}$ Briefly, blocks of semi-frozen frontal lobes were stripped of leptomeninges and diced into small pieces. Tissue was digested overnight with proteinase $\mathrm{K}$ (final concentration $0 \cdot 25$ $\mathrm{mg} / \mathrm{ml}$ in $10 \mathrm{mM}$ TRIS- $\mathrm{HCl}, \mathrm{pH} 7 \cdot 4,1 \mathrm{mM}$ EDTA, and $0.5 \%$ sodium dodecyl sulphate (SDS)) at $56^{\circ} \mathrm{C}$. DNA was subsequently purified using standard methods. ${ }^{9}$

Paraffin wax embedded sections $(10 \mu \mathrm{m})$ were cut and placed in a $1.5 \mathrm{ml}$ Eppendorf 
Results of PCR detection with pathological and immunohistochemical findings

\begin{tabular}{|c|c|c|c|c|c|c|c|c|}
\hline \multirow{2}{*}{$\begin{array}{l}\text { Case } \\
\text { No }\end{array}$} & \multirow[b]{2}{*}{ Sex } & \multirow{2}{*}{$\begin{array}{l}\text { Age } \\
\text { (years) }\end{array}$} & \multirow{2}{*}{$\begin{array}{l}\text { Delay } \\
\text { of PM } \\
\text { (days) }\end{array}$} & \multirow{2}{*}{$\begin{array}{l}\text { Fixation } \\
\text { (months) }\end{array}$} & \multirow{2}{*}{$\begin{array}{l}\text { Neuropathological } \\
\text { diagnosis }\end{array}$} & \multirow{2}{*}{$\begin{array}{l}H I V \\
p 24\end{array}$} & \multicolumn{2}{|c|}{$P C R$} \\
\hline & & & & & & & $F$ & $P$ \\
\hline 1 & $\mathbf{M}$ & 31 & 1 & 5 & HIV encephalitis & + & + & + \\
\hline 2 & $\mathbf{M}$ & 29 & 1 & 5 & No abnormalitis & - & - & - \\
\hline 3 & $\mathbf{M}$ & 39 & 4 & 3 & PML & + & + & + \\
\hline 4 & $\mathbf{M}$ & 53 & 3 & 1 & HIV encephalitis & + & + & + \\
\hline 5 & $\mathbf{M}$ & 42 & 3 & 5 & Lymphoma & + & + & + \\
\hline 6 & $\mathbf{M}$ & 25 & 2 & 3 & $\begin{array}{l}\text { HIV encephalitis, } \\
\text { cryptococcosis }\end{array}$ & - & + & + \\
\hline 7 & $\mathbf{M}$ & 26 & 2 & 7 & Ischaemic foci & - & - & - \\
\hline 8 & $\mathbf{M}$ & 47 & 3 & 1.5 & Ischaemic foci & - & - & - \\
\hline 9 & $M$ & 28 & 2 & 2 & Cryptococcosis & - & + & + \\
\hline 10 & $\mathbf{M}$ & 40 & 1 & 2 & Non-specific gliosis & + & + & + \\
\hline 11 & $\mathbf{M}$ & 30 & 2 & 6 & Non-specific gliosis & + & + & + \\
\hline 12 & $\mathbf{M}$ & Not known & a 1 & 2 & HIV encephalitis & + & + & + \\
\hline 13 & $\mathbf{M}$ & 25 & 1 & 4 & CMV encephalitis & - & + & + \\
\hline 14 & $\bar{M}$ & 43 & 17 hours & 6 & $\begin{array}{l}\text { HIV and CMV } \\
\text { encephalitis }\end{array}$ & - & + & + \\
\hline 15 & $\mathbf{M}$ & 49 & 2 & 3 & HIV encephalitis & + & + & + \\
\hline 16 & $\mathbf{M}$ & 67 & 3 & 3 & No abnormalitis & - & + & - \\
\hline 17 & $\mathbf{M}$ & 35 & 2 & 1 & Tuberculosis & - & + & + \\
\hline 18 & $\mathbf{M}$ & 51 & 4 & 6 & CMVE encephalitis & - & - & - \\
\hline 19 & $\mathbf{M}$ & 52 & 4 & 8 & HIV encephalitis, FPL & + & + & + \\
\hline 20 & $\mathbf{M}$ & 32 & 1 & 2 & No abnormalities & - & + & + \\
\hline
\end{tabular}

PML = progressive multifocal leucoencephalopathy; $\mathrm{CMV}=$ cytomegalovirus; $\mathrm{FPL}=$ focal pontine leucoencephalopathy; $F=$ frozen tissue; $P=$ paraffin wax embedded tissue.

tube. The number of sections varied according to the area of the tissue block; as our frontal blocks have a standard size, $10 \mathrm{sec}$ tions were cut from each case. Paraffin was removed by washing with xylene for $15 \mathrm{~min}$ utes with three changes and then with $100 \%$ ethanol for five minutes, followed by drying at

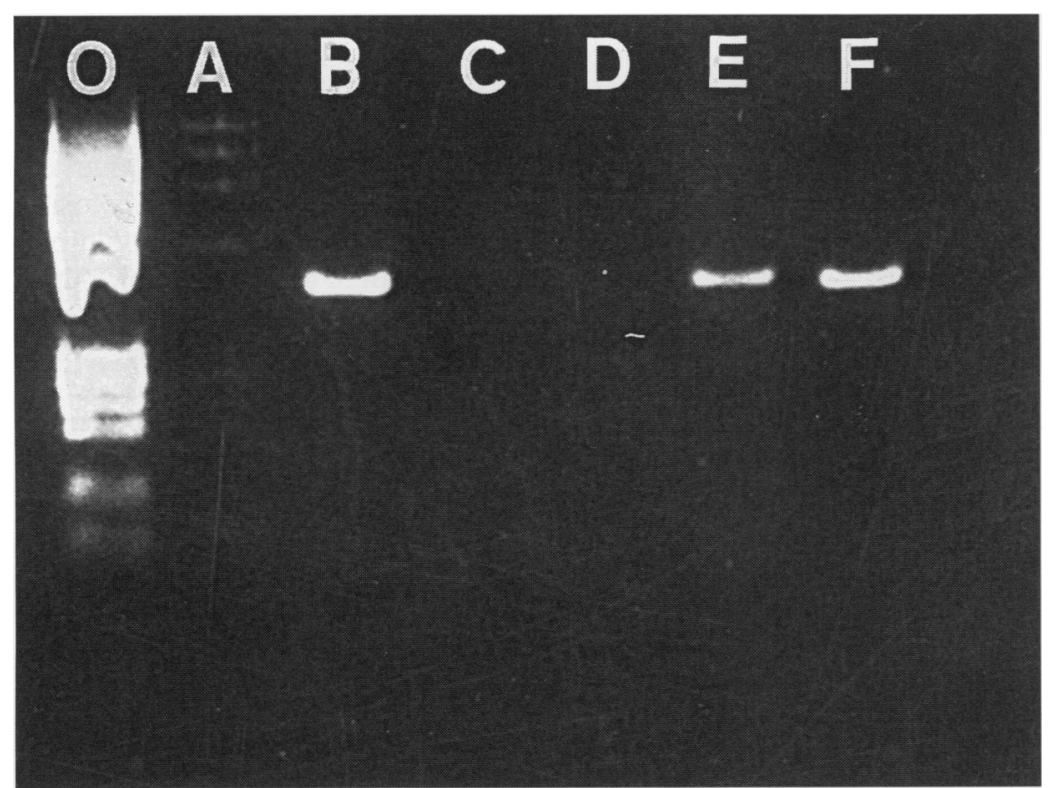

(A)

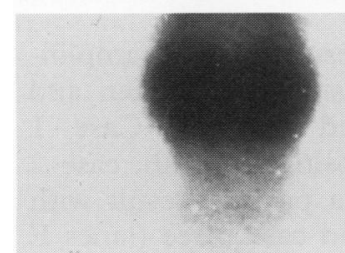

A

B

C

D

E

$\mathbf{F}$

(B)

Figure 1 Results of PCR amplification to detect the HIV gag gene in a variety of samples of the PCR reference kit. (A) Electrophoresis. (B) Southern blot hybridisation. Lane $A$ shows a negative control consisting of carrier DNA alone; lanes $B$ to $F$ show the results using known copy numbers of HIV plasmid DNA lane $B, 1000$ molecules; lane $C, 0 \cdot 1$ molecules; lane $D, 1$ molecule; lane $E, 10$ molecules; lane $F, 100$ molecules; lane $O$ in $(A)$, DNA molecular weight marker). $95^{\circ} \mathrm{C}$ for about 30 minutes. Tissue was digested with proteinase $\mathrm{K}$ at a final concentration of $5 \mathrm{mg} / \mathrm{ml}$ in $10 \mathrm{mM}$ TRIS- $\mathrm{HCl}, \mathrm{pH}$ 7.4, $1 \mathrm{mM}$ EDTA, and 0.5\% SDS. Digestion took place at $55^{\circ} \mathrm{C}$ for 24 to 48 hours in tubes which were shaken periodically. The supernatant fluid was extracted once with an equal volume of phenol (equilibrated with $100 \mathrm{mM}$ TRIS- $\mathrm{HCl}, \mathrm{pH} 8 \cdot 0$, and protected by $0 \cdot 1 \%$ hydroxyquinoline), subsequently several times with a $1 / 1$ mixture of phenol and chloroform (a 24/1 (v/v) mixture of chloroform and isoamylalcohol), and finally once with chloroform. The supernatant fluid was passed through a Microcon-30 filter (Amicon, Gloucs, UK) using an Eppendorf centrifuge at $13000 \times g$ for 10 minutes. The initial volume of $0.5 \mathrm{ml}$ was finally reduced to about 5-20 $\mu \mathrm{l}$. The residue was washed once with $0.5 \mathrm{ml}$ distilled water and used for amplification. DNA was quantified using the ethidium bromide saran wrap method. ${ }^{9}$

PCR ANALYSIS

Human single copy gene $\beta$-globin was used as a DNA positive control and only clearly positive samples were used for HIV PCR analysis.

Ten molecules of non-infectious plasmid containing a completely rearranged HIV sequence (provided by UK Medical Research Council (MRC), AIDS Directed Programme (ADP), PCR Reference Centre) were used as the HIV positive control. DNA from brain tissue of patients not in any HIV risk group was used as a negative control.

All the primer sequences are written from $5^{\prime}$ to 3'. Two human $\beta$-globin primers (MRC, ADP, National Institute for Biological Standards and Control (NIBSC)) were used: ADP894.1, ACA CAA CTG TGT TCA CTA GC; ADP894.2, CAA CTT CAT CCA CGT TCA CC. A 110 base pair (position 14-123) fragment is flanked by primers ADP894. 1 and ADP894.2. Two HIV primers 3855/1 and 3855/2 (Perkin Cetus Elmer UK) were used: $3855 / 1$ (SK145), AGT GGG GGG ACA TCA AGC AGC CAT GCA AAT; 3855/2 (SK431), TGC TAT GTC AGT TCC CCT TGG TTC TCT. A 142 base pair (position 1366-1507) fragment is flanked by primers $3855 / 1$ and $3855 / 2$.

Of the reaction mixture, $50 \mu 1$ contained $0.5 \mu \mathrm{M}$ of each primer, $0.2 \mathrm{mM}$ of dATP, dCTP, dGTP, and dTTP, and 2.5 units of Amplitaq DNA polymerase in PCR buffer (10 $\mathrm{mM}$ TRIS- $\mathrm{HCl}, \mathrm{pH} 8 \cdot 3,50 \mathrm{mM} \mathrm{KCl}, 1.5$ $\mathrm{mM} \mathrm{MgCl}$, and $0.001 \%$ gelatin). Forty cycles of PCR were performed with 0.5-1 $\mu \mathrm{g}$ extracted template DNA, each cycle consisting of thermal denaturation at $94^{\circ} \mathrm{C}$ for one minute, primer annealing at $55^{\circ} \mathrm{C}$ for two minutes, and extension at $72^{\circ} \mathrm{C}$ for three minutes.

Human $\beta$-globin gene amplification was similar to HIV amplification except that the annealing temperature for $\beta$-globin gene amplification was $60^{\circ} \mathrm{C}$ and $0.1 \mu \mathrm{M}$ of primers were used in the PCR reaction. Amplified products were visualised by ethidium bromide staining of agarose gel electrophoresis. HIV products 
were further detected by Southern blot hybridisation to ascertain their specificity.

\section{SOUTHERN BLOT HYBRIDISATION}

To detect the 142 base pair PCR product, modified Saluz and Jost ${ }^{10}$ "filling in" methods were applied as described before. ${ }^{2}$ Oligonucleotides were provided by the MRC, $\mathrm{ADP}$, and NIBSC. Their sequences are: gag (30-mer), 5'-CAT CAA TGA GGA AGC TGC AGA ATG GGA TAG; (10-mer), 5'TCC CAT TCT G. Briefly, an annealing mix containing $10 \mu \mathrm{l}$ of the 30 -mer, $10 \mu \mathrm{l}$ of the 10 -mer, and $2.5 \mu \mathrm{l}$ of the ologonucleotide labelling buffer was prepared and incubated at $75^{\circ} \mathrm{C}$ for two minutes, at room temperature for 20 minutes and on ice for 10 minutes. This was followed by incorporation of digoxigenin-11-dUTP and precipitation of the probe by ethanol.

Nylon membranes (Boehringer Mannheim, UK) were prehybridised for more than one hour at $42^{\circ} \mathrm{C}$ in hybridisation buffer $(5 \times$ saline-sodium citrate (SSC), $50 \%$ formamide, $0.1 \% \mathrm{~N}$-lauroylsarcosine, $0.02 \%$ SDS, and $2 \%$ blocking reagent) and then hybridised overnight at $42^{\circ} \mathrm{C}$ with $200 \mathrm{ng} / \mathrm{ml}$ labelled probe. They were then washed in $0.2 \times$ SSC

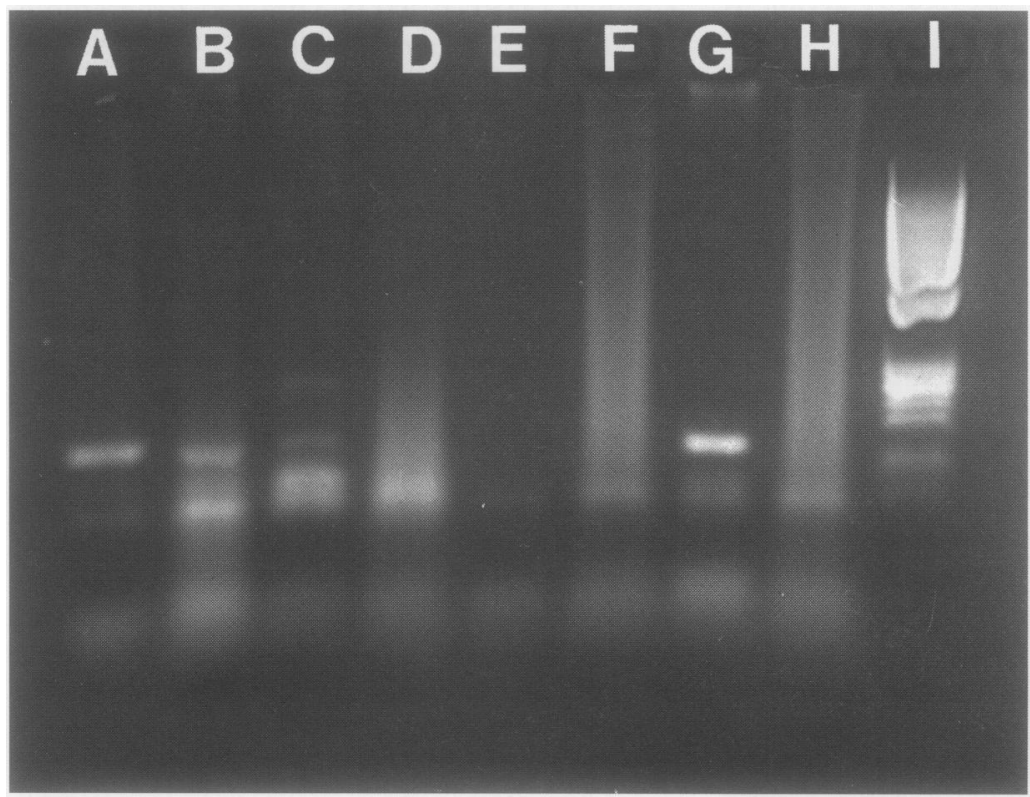

(A)

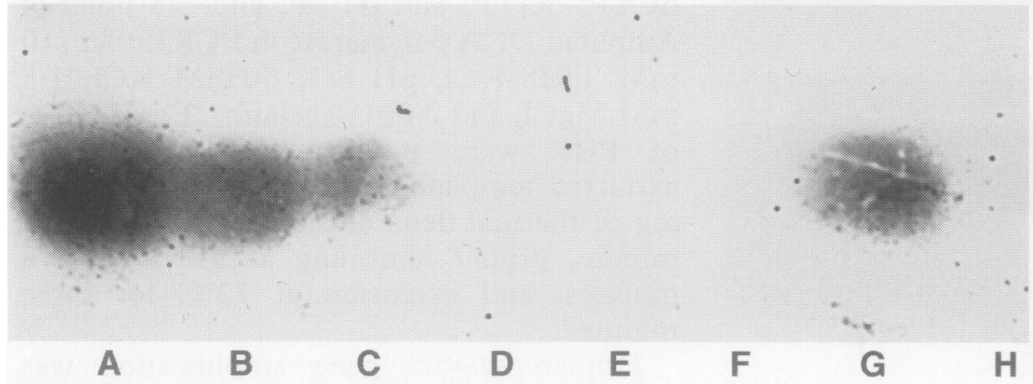

(B)

Figure 2 Results of PCR amplification of DNA from frozen and paraffin wax embedded specimens in three cases. (A) Electrophoresis. (B) Southern blot hybridisation. In lanes $A$, $C$, and $E D N A$ was extracted from fresh frozen samples and in lanes $B, D$, and $F$ it was extracted from paraffin wax embedded tissue; lane $G, H I V$ plasmid DNA positive control; lane $H$, normal brain negative control; lane I in $(A), D N A$ molecular weight marker. and $0.1 \%$ SDS at room temperature for one hour with four changes.

Colorimetric detection using nitroblue tetrasodium and X-phosphate was performed according to the Boehringer Mannheim protocol. " Briefly, after incubation with antidigoxigenin-alkaline phosphatase at room temperature for 30 minutes and a postincubation wash, the filter was incubated in substrate to permit colour development.

\section{Results}

Figure 1 illustrates the results of PCR amplification with the oligonucleotide probe for the HIV gag gene in a variety of samples of the PCR reference kit. The result of this test shows that 10 molecules of HIV-1 DNA gave a clear signal after Southern blot hybridisation. There were no false positive results following either PCR amplification or Southern blot hybridisation.

The neuropathological changes observed in the brain tissue of the 20 patients with AIDS included in this study are summarised in the table. HIV encephalitis was present in seven cases; other neuropathological findings included cytomegalovirus encephalitis (three cases), progressive multifocal leucoencephalopathy (one case), cryptococcosis (two cases), lymphoma (one case), tuberculosis (one case), and non-specific changes (four cases); three cases did not show any abnormalities. Nine cases, including all those with neurological evidence of HIV encephalitis, were HIV p24 positive.

Specimens were regarded as positive or negative whenever PCR results were consistently positive or negative (PCR amplifications were repeated three times). Samples that were positive in only one or two of three tests (cases 12 and 17-20 in the table) were defined as indeterminate, ${ }^{2}$ and underwent another five tests, on the basis of which they were reclassified as positive (four cases) or negative (one case).

Sixteen cases were positive on analysis of frozen specimens. These included all those with immunohistochemical evidence of HIV. Of these, 15 were also positive when paraffin wax embedded material was analysed. Southern blot hybridisation confirmed the positive results. None of the cases positive on analysis of paraffin wax embedded samples gave negative results when frozen tissue was examined.

Figure 2 shows the results of PCR amplification in three cases using both frozen and paraffin wax embedded samples. Case 1 (lanes A and B) was positive in both; case 2 (lanes $C$ and $D$ ) gave a positive result with frozen material only; and case three (lanes $\mathrm{E}$ and F) is an example of the four cases with negative results on analysis of both frozen and paraffin wax embedded material.

\section{Discussion}

In this study we have shown that HIV proviral DNA can be detected by PCR in brain tissue 
of patients with AIDS using formalin fixed, paraffin wax embedded tissue. The HIV primers used were chosen so as to amplify a specific sequence of the HIV gag region. As in a previous study, ${ }^{2}$ gag primers produced more reliable results than pol or env primers, and highly conserved areas have been identified in the HIV-1 genome in long terminal repeat sequences and in the gag gene. ${ }^{8}$ Moreover, as the region spanning the gag sequence is thought to be the last to be synthesised during reverse transcription, positive results using the gag region reflect completely or almost completely synthesised viral DNA. ${ }^{8}$

In a previous investigation using $\mathrm{PCR}^{2}$ specimens were classified as positive, negative, or indeterminate depending on whether most of the tests were positive; all tests were negative; or one or two only were positive, respectively. In the present study each indeterminate case underwent five additional tests and samples were defined as positive when at least three of the latter gave positive results.

Of the 20 cases in this study, 16 were positive on analysis of frozen samples; of the latter, 15 were also positive when paraffin wax embedded material was studied. On the other hand, none of those which were negative on analysis of frozen samples gave positive results on analysis of paraffin wax embedded sections. Positive cases on analysis of both frozen and paraffin wax embedded material included the seven with morphological and immunohistochemical evidence of HIV encephalitis. A possible explanation for the single negative result (fig 2) could be the presence of an inhibitor of Taq polymerase. ${ }^{12}{ }^{13}$ Although the human $\beta$-globin gene was successfully amplified in this case, the degree of inhibition may not have been uniform for the different sets of primers. ${ }^{14}$

Several investigators have drawn attention to the effects of various fixatives and fixation times on PCR results. ${ }^{15-17}$ In this study the specimens had been kept in $10 \%$ buffered formalin (the most widely used fixative in neuropathology) for one to eight months, and the results show that even relatively long fixation times are compatible with successful amplification of HIV. However, DNA extracted from paraffin wax blocks will probably need to be concentrated using a microconcentrator instead of ethanol precipitation (data not shown).

The PCR technique has been used to amplify specific DNA from paraffin wax embedded human tissue in a variety of disorders. Human papillomavirus was identified by Brandwein et al, ${ }^{18}$ Nawa et al, ${ }^{19}$ Ohta and Ikeda, ${ }^{20}$ Saltzstein et $a l,{ }^{21}$ Van-Bommel et $a l,{ }^{22}$ and Kellokoski et $a l^{23}$; an adenovirus, cytomegalovirus, and herpes simplex virus (HSV) 1 and 2 were detected by Vesy $e t a l,{ }^{24}$ whilst Epstein-Barr virus (EBV) was detected by Niedermeyer et $a l^{25}$ and Morshed et $a l^{26}$ and hepatitis $\mathrm{C}$ virus by Bresters et $a .^{27}$ Central nervous system (CNS) tissue specimens were used by Woodall et $a l^{28}$ for the identification of enterovirus RNA; Nicoll et $a l^{29}$ detected HSV1 DNA in the brains of patients with herpes encephalitis and Lager et $a l^{30}$ detected EBV in the brains of patients with primary biliary cirrhosis. Morgello ${ }^{31}$ examined EBV and HIV in 12 AIDS related primary CNS lymphomas and detected EBV in six of the 12 tumours but could not detect HIV; Lai-Goldman et al detected EBV in various organs of patients with AIDS but not in the brain. In this study we have shown not only that HIV proviral DNA can be detected by PCR in paraffin wax embedded tissue from the CNS but also that the results have the same degree of reliability as those obtained using fresh frozen material.

Supported by a grant from the Brain Research Trust and MRC (SFA and FS), and the European Concerted Action on AIDS (FS). AC is a recipient of a grant from the Istituto Superiore di Sanità of Italy.

We thank Dr S Lucas and Mr M Karseras for providing the brain tissue, and Mr A Beckett for the detection of the HIV core protein p24. We are grateful to the Medical Research Council, AIDS Directed Programme repository, and the National Institute of Biological Standards and Control for proNational Institute of Biologica
viding primers and probes.

1 Openshaw H, Cantin E, Hinton D, Angeles L. HIV detection by polymerase chain reaction in AIDS brains. Neurology 1989:39(Suppl 1):379.

2 Sinclair E, Scaravilli F. Detection of HIV proviral DNA in Cortex and white matter of AIDS brains by non-isotopic Cortex and white matter of AIDS brains by non-isotopic polymerase chain reaction: correlation
poliodystrophy. AIDS 1992;6:925-32.

3 Sinclair E, Gray F, Scaravilli F. PCR detection of HIV proviral DNA in the brain of an asymptomatic HIVpositive patient. $\mathcal{F}$ Neurol 1992;239:469-70.

4 Wiestler OD, Leib SL, Brustle O, Spiegel H, Kleihues P. Neuropathology and pathogenesis of HIV encephalopathies. Acta Histochem Suppl 1992;42:107-14.

5 Lyman WD, Kress Y, Kure K, Rashbaum WK, Rubinstein A, Soeiro R. Detection of HIV in fetal central nervous system tissue. AIDS 1990;4:917-20.

6 Vazeux R, Lacroix-Ciaudo C, Blanche S, Cumont MC, Henin D, Gray F, et al. Low levels of human immunodeficiency virus replication in the brain tissue of children with severe acquired immunodeficiency syndrome encephalopathy. Am F Pathol 1992;140:137-44.

7 Lai-Goldman M, Lai E, Grody WW. Detection of human immunodeficiency virus (HIV) infection in formalinfixed, paraffin-embedded tissues by DNA amplification. Nucleic Acid Res 1988;16:8191.

8 Pang S, Koyanagi Y, Miles S, Wiley C, Vinters HV, Chen ISY. High levels of unintegrated HIV-1 DNA in brain tissue of AIDS dementia patients. Nature 1990;343: 85-9.

9 Sambrook J, Fritsch EF, Maniatis T. Molecular cloning. A laboratory manual. 2nd edn. New York: Cold Spring Harbor Laboratory, 1989.

10 Saluz H, Jost JP. A simple high-resolution procedure to study DNA methylation and in vivo DNA-protein interactions on a single-copy gene level in higher eukaryotes. Proc Natl Acad Sci USA 1986;86:2602-6.

11 Boehringer Mannheim Biochemica. Detection of DIGlabeled nucleic acids. In: The DIG system user's guide for filter hybridization. Mannheim, Germany: Boehringer Mannheim Biochemica, 1993:49-60.

12 An SF, Fleming KA. Removal of inhibitor(s) of the polymerase chain reaction from formalin fixed, paraffin wax embedded tissues. 7 Clin Pathol 1991;44:924-7.

13 De Franchis R, Cross NCP, Foulkes NS, Cos TM. A potent inhibitor of Taq polymerase copurified with
human genomic DNA. Nucleic Acid Res 1988;16:10355.

14 Coutlée F, Viscidi RP, Saint-Antoine P, Kessous A, Yolken RH. The polymerase chain reaction: a new tool for the understanding and diagnosis of HIV-1 infection at the molecular level. Mol Cell Probes 1991;5:241-59.

15 Bramwell NH, Burns BF. The effects of fixative and fixation time on the quantity and quality of extractable DNA for hybridization studies on lymphoid tissue. Exp Hematol 1989;16:730.

16 Wu AM, Ben Ezra J, Winberg C, Colombero AM, Rappaport H. Analysis of antigen receptor gene rearrangements in ethanol and formaldehyde-fixed paraffin-embedded specimens. Lab Invest 1990;63: paraffin-

17 Tokuda Y, Nakamura T, Satonaka K, Meada S, Doi K, Baba S, et al. Fundamental study on the mechanism of Baba $S$, et al. Fundamental study on the mechanism of DNA degradation in tissues

18 Brandwein MS, Nuovo GJ, Biller H. Analysis of prevalence of human papillomavirus in laryngeal carcinomas. Study of 40 cases using polymerase chain reaction and consensus primers. Ann Otol Rhinol Laryngol 1993; 102:309-13.

19 Nawa A, Nishiyama Y, Kikkawa F, Kawai M, Mano H, Goto S, et al. Detection of human papillomaviruses from histological normal lymph nodes of Japanese cervica 
cancer patients by nested polymerase chain reaction assay. Int $\mathcal{f}$ Cancer 1993;53:932-7.

20 Ohta $M$, Ikeda $M$. The sionificance of HPV 16, 18 infection and the DNA ploidy associated with the progression of uterine cervical dysplasia. Nippon Sanka Fujinka Gakkai Zasshi 1993;45:540-6.

21 Saltzstein DR, Orihuela E, Kocurek JN, Payne DA, Chan TS, Tyring SK. Failure of the polymerase chain reaction (PCR) to detect human papilloma virus (HPV) in transitional cell carcinoma of the bladder. Anticancer Res 1993;13:423-5

22 Van-Bommel PF, Van-den-Brule AJ, Helmerhorst TJ, Gallee MP. HPV DNA presence and HPV genotypes as prognostic in low-stage squamous cell cervical cancer. Gynecol Oncol 1993;48:333-7.

23 Kellokoski JK, Syrjanen SM, Chang F, Yliskoski M, Syrjanen KJ. Southern blot hybridization and PCR in detection of oral human papillomavirus (HPV) infections in women with genital HPV infections. $f$ Oral tions in women with genit
Pathol Med 1992;21:459-64.

24 Vesy CJ, Greenson JK, Papp AC, Snyder PJ, Qualman SJ, Prior TW. Evaluation of celiac disease biopsies for adenovirus 12 DNA using a multiplex polymerase chain reaction. Mod Pathol 1993;6:61-4.

25 Niedermeyer H, Fellbaum C, Hansmann ML, Kraus I, Alavaikko MJ, Busch R, et al. Influence of Epstein-Bar virus genome on patient survival in Hodgkin's disease. Verh Dtsch Ges Pathol 1992;76:173-6.

26 Morshed SA, Nishioka M, Saito I, Komiyama K, Moro I. Increased expression of Epstein-Barr virus in primary Increased expression of Epstein-Barr virus in primary biliary

27 Bresters D, Cuypers HT, Reesink HW, Chamuleau RA Schipper ME, Boeser-Nunnink BD, et al. Detection of hepatitis $C$ viral RNA sequences in fresh and paraffinembedded liver biopsy specimens of non-A, non-B hepatitis patients. F Hepatol 1992;15:391-5.

28 Woodall CJ, Watt NJ, Clements GB. Simple technique for detecting RNA viruses by PCR in single sections of wax embedded tissue. $f$ Clin Pathol 1993;46:276-7.

29 Nicoll JA, Kinrade E, Love S. PCR-mediated search for herpes simplex virus DNA in sections of brain from patients with multiple sclerosis and other neurological disorders. F Neurol Sci 1992;113:144-51.

30 Lager DJ, Burgart LJ, Slagel DD. Epstein-Barr virus detection in sequential biopsies from patients with a detection in sequential biopsies from patients with a
posttransplant lymphoproliferative disorder. Mod Pathol posttransplan

31 Morgello S. Epstein-Barr and human immunodeficiency viruses in acquired immunodeficiency syndrome-related primary central nervous system lymphoma. Am f Pathol 1992;141:441-50. 